\title{
How to Deal With and Repair Broken Trust in an R\&D Partnership
}

\author{
Anna Brattström
}

\author{
" Rebuilding trust when it's been broken is not dependent") \\ only on the person who has broken it, or how many \\ times they can prove they are honest. It depends on the \\ person who has decided not to trust anymore. Though \\ they may be totally justified in their decision not to trust, \\ as long as they choose not to, the relationship has no \\ hope of survival and should be ended. If or when they \\ decide to trust again, there is hope reborn.
}

\author{
Doe Zantamata \\ Author of Happiness in Your Life
}

\begin{abstract}
This article offers an actionable framework for dealing with trust violations in $R \& D$ partnerships: it explains how to turn around a conflicted R\&D partnership, repair trust, and learn from the experience. As innovation becomes more open, firms increasingly find themselves involved in $R \& D$ collaborations with suppliers, customers or even competitors. Trust plays a fundamental role in such partnerships to work. Yet, trust cannot be taken for granted. In fact, trust in R\&D partnerships is often violated - and without executive intervention, trust violations can soon turn even the most promising partnership into a value-destroying predicament. Although much has been written about trust formation in R\&D partnerships, this article focuses instead on what to do when trust has been broken. The analysis is based on a review of academic research and is illustrated with real-life examples of trust repair processes.
\end{abstract}

\section{Introduction}

R\&D partnerships are vital sources of innovation and competitive advantage for firms across many industries. As products become increasingly complex and technology becomes increasingly advanced, R\&D partnerships are formed between service firms and manufacturers, between hardware and software developers, between OEMs and their suppliers - even between competitors. The upside is enormous. By sharing knowledge and pooling resources, partnering firms are able to develop cutting-edge technology across a range of areas that no firm could have covered on its own.

Trust is a core currency in such partnerships. Trust facilitates learning and knowledge exchange. Trust allows firms to collaborate under uncertain conditions when it is impossible to write a full contract. In short, the research evidence is clear: there is a strong and significant correlation between trust and collaborative performance in R\&D partnerships (Gulati \& Nickerson, 2008; Krishnan et al., 2006; Poppo et al., 2016). Yet, seasoned executives know all too well that, although trust takes a long time to build, it can only take a minute to destroy. In particular, when costs increase more than expected and project delays strain patience (which is, after all, the rule more than the exception in a context of innovation), collaborating partners may turn out to be more opportunistic than initially expected. They might shirk, leak information, try to push costs onto one another, or behave in a way that causes the initial trust to disappear and distrust to emerge. Such loss of trust is a real problem. Once trust disappears, $R \& D$ partnerships are likely to descend a slippery slope of increasingly harsh interactions and an atmosphere of wariness, watchfulness, and vigilance (Ariño \& de la Torre, 1998; Doz, 1996), often leading to expensive divorces (Gulati et al., 2008). In this situation, a core question becomes: how can firms deal with trust violations when they occur and how can trust be rebuilt over time? 


\section{How to Deal With and Repair Broken Trust in an R\&D Partnership}

\section{Anna Brattström}

In this article, I address that core question. Actionable advice already exists about how to assess initial trust (e.g., Kunttu, 2017; Moraes, 2010) build trust (e.g., Arino et al., 2001), or exit R\&D partnerships once trust is broken (e.g., Gulati et al., 2008). My analysis complements this prior work by developing a framework that addresses how to deal with trust violations when they occur, then repair trust, learn from the experience, and continue to reap the benefits of collaboration. For managers, this knowledge is important. Because there is no such thing as a perfect partnership, learning how to work together - instead of splitting up - can become a valuable source competitive advantage in the longer run. For scholars interested in inter-organizational trust repair (e.g., Bachmann et al., 2015; Brattström et al., 2018; Doz, 1996; Faems et al., 2008), the framework that I develop in this article offers an integrative perspective of how different trust repair tactics work in conjunction.

\section{Method}

The framework in this article is based on a thorough review of current research on how to build, maintain, and repair trust in $R \& D$ partnerships. I searched for the words "trust", "trust repair", "relationship repair", and "transgression" in major European and North American journals. This allowed me to identify a rich body of research that addresses this particular phenomenon. I used this literature in two specific ways.

First, I leveraged conceptual work that discusses the dynamics of trust, distrust, and trust repair (Bachmann et al., 2015; Dirks et al., 2009; Gillespie \& Dietz, 2009; Lewicki \& Brinsfield, 2017; Lewicki et al., 1998; Lewicki \& Wiethoff, 2000). This conceptual work offers rich insights into the dynamics of trust repair processes, including how they differ from processes of trust building. Moving beyond these prior conceptual studies, my analysis focused specifically on the context of R\&D partnerships and the particular opportunities and challenges of repairing trust in this context. Here, the results of my analysis are written with a practitioner audience in mind.

Second, I drew on empirical research on inter-organizational trust breakdown and repair. In particular, I leveraged the richness of longitudinal, qualitative studies that have been published on this topic, where authors have provided rich insights into different trust breakdown repair processes between organizations (e.g., Ariño \& de la Torre, 1998; Brattström et al., 2018; Doz, 1996; Faems et al., 2008). Each of these studies explores a particular facet of inter-organizational trust repair, such as the role of contracts (Faems et al., 2008) or shielding off (Brattström et al., 2018). The purpose of my analysis, in contrast, is to provide an integrative perspective: to identify the strength and weaknesses of different trust repair strategies and to discuss how they can be used in conjunction. To support my conclusions and recommendations, I provide detailed references to the original sources.

\section{Why Trust Is Needed in R\&D Partnerships}

An $R \& D$ partnership is "the specific set of different modes of inter-firm collaboration where two or more firms, that remain independent economic agents and organizations, share some of their R\&D activities" (Hagedoorn, 2002). An R\&D partnership is a leap into the unknown. Because it is inherently about innovation, partners cannot fully predict the outcome, the duration, the cost, nor the benefits of collaboration. They can only hope that both partners will do what it takes to succeed. Trust enables such hope. To trust is to take a leap of faith - to put your destiny in another's hands.

When a firm is in control of its partner, trust is desirable but not essential (Brattström \& Bachmann, 2018). In most cases, however, firms find themselves in $R \& D$ partnerships where they are not in full control but are nevertheless dependent on the actions of a partner. In these cases, trust is more than "nice to have" because it allows partners to interact without being paralyzed by fear of loss. For example, trust enables the exchange of sensitive information or complex knowledge. Trust promotes constructive dialogue, stimulates creativity, and thereby leads to productive progress in work tasks. In fact, trust is much more than a "feel good" factor: there is a clear and powerful link between trust and performance in R\&D partnerships (Gulati \& Nickerson, 2008; Krishnan et al., 2006; Poppo et al., 2016).

Trust is built incrementally as partners interact with each other over time (Zaheer et al., 1998). Usually, this starts with personal relationships, which are gradually extended so that there is not only trust between individuals, but a more generalized and institutionalized trust between the collaboration organizations. In such cases, the relationship becomes characterized by hope, faith, confidence, and assurance (Mayer et al., 1995).

If trust is violated, this positive spiral of incremental trust-building is broken. Negative stories start to spread, leading to a polarization between the two firms and a decline in trust in the R\&D partnership. Since 


\section{How to Deal With and Repair Broken Trust in an R\&D Partnership}

\section{Anna Brattström}

trust violations often provoke a desire for retaliation, this initiates an escalating, negative spiral: trust violations become increasingly frequent, leading to further deterioration of trust and additional trust violations (Lewicki et al., 1998). Eventually, distrust becomes ingrained into the $R \& D$ partnership (Kroeger, 2012), representing confident negative expectations about each partner's future conduct (Lewicki et al., 1998). Depending on the nature of the violation, this distrust can imply expectations about the partner being honest but incompetent, dishonest but competent, or the twofold setback of being both dishonest and incompetent. When this happens, collaboration suffers. Information does not flow as easily, learning is hampered, attention and efforts are spent on fighting instead of collaboration, deteriorating motivation and draining the partnership from energy. The research evidence is clear: if collaborating partners fail to deal with this negative spiral, chances are that the R\&D partnership ends up in a costly divorce (Ariño \& de la Torre, 1998).

\section{What to Do When Trust Is Violated: Exit, Buy, or Repair?}

After a trust violation, it is easy to get carried away as the conflict escalates. The intuitive reaction is to call in the lawyers and ask them: "How soon can we get out of this R\&D partnership?" This, however, is the wrong question. Executives need to keep a cool head and instead ask themselves: "How dependent are we on this partner?"

Below is a one-minute checklist that can be used to assess the degree of interdependence in a specific R\&D partnership. It shows that there are many different reasons why dependence occurs. Dependence is stronger when investments are made within the R\&D partnership that have little value outside it (Pfeffer \& Salancik, 1978). Dependence also increases when a partner has made long-term investments that will not return a profit if that partner pulls out of the R\&D partnership too early. It may also be that the technical design of a co-created product or the working practices of the firms are so deeply intertwined that tearing them up and starting over with a new partner is both expensive and risky. Moreover, in many industries, there are not that many alternative partners to turn to, which further increases dependence.

Exit is a preferable option under weak-to-moderate dependence. Negative trust spirals are, after all, difficult to turn around. If dependence on the partner is low, it

\section{How dependent is our firm on this partner?}

Check all that apply:

We have invested in equipment, know-how, or staff that are of little use outside of this partnership.

The technical designs of our respective products are deeply integrated.

We have developed shared routines, a common terminology, or a shared database with our partner.

There are few alternative partners that can do the same work, and we cannot do it in-house.

If trust is broken, do we exit, buy, or repair?

Score +1 for each box checked and compare the total:

0: Dependence seems low: consider exit before throwing more good money after bad.

1-2: Dependence seems moderate: consider trust repair as a good alternative.

3-4: Dependence seems high: consider trust repair or acquisition.

Figure 1. Checklist for assessing partner dependence following a violation of trust in an R\&D partnership 


\section{How to Deal With and Repair Broken Trust in an R\&D Partnership}

\section{Anna Brattström}

is better to leave too soon than too late. Acquisition, on the other hand, is preferable under moderate-to-strong dependence. Through acquisition, joint work is continued, but the majority owner gets to call the shots, need not worry about information leakage, and enjoys all the profit in the end.

Both exit and acquisition, however, come with substantial risks. Because firms benefit most from R\&D partnerships when they intend to continue collaborating for a long time (Gulati \& Nickerson, 2008), being too eager to exit can undermine the R\&D partnership from the start. Acquisition is not easy either. By growing in size and complexity, the acquiring firm becomes less agile. Instead of sharing the risks associated with the joint task with a partner, the acquiring firm takes them all on itself. Moreover, acquisitions surprisingly often prove to be value-destroying rather than value-creating when partners struggle to integrate two different firms (Cartwright \& Cooper, 1993). When both exit and acquisition are difficult or too drastic, repairing trust can become an alternative. In the following section, I discuss this alternative, presenting executive tactics for repairing trust.

\section{Trust Repair: A Long-Term Alternative to Exit or Acquisition}

Building initial trust requires a step-by-step process during which partners slowly but steadily learn about each other. In contrast, repairing trust requires drastic action. Once the level of trust has dropped below zero, incremental trust-building activities - such as showing commitment, consistency, and honesty - are simply too vague and weak to turn round the negative spiral. Figure 2 provides one way to think about the difference between incremental trust-building and trust repair.

As illustrated in Figure 2, trust repair starts from a negative state that is characterized by watchfulness, wariness, fear, and skepticism (Lewicki et al., 1998). To repair trust, partners must first overcome this negativity. They must break away from the tit-for-tat retaliation that follows from violations and that escalate distrust. And, they must put a stop to the negative gossip, stories, and rumours that often spread following a trust violation, and that lead to the diffusion of distrust within the firm. On this point, repairing trust between two organizations is different from repairing trust

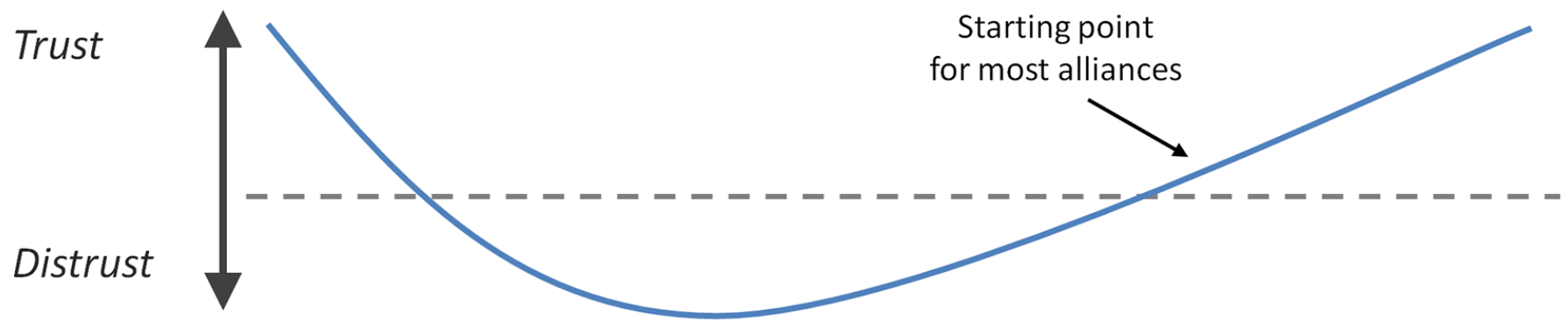
Phase
Trust Breakdown
Trust Repair
Step 1. Stop escalation Step 2. Build a platform
Step 3. Build trust incrementally

\section{Critical activities} during this phase
Distrust escalates since trust violations provoke retaliations and negative stories spread within the organization.

Watchfulness, wariness, fear, and skepticism.
One or both partners put a stop to escalation by refusing "tit for tat" retaliations and hindering negative gossip.
Partners substantially change their way of working in order to collaborate even though distrust is still present.
Trust is incrementally built as partners show commitment, consistency, and honesty.
Relationship characteristics
The relationship is cooled down, but distrust persists.
There is an expectation that joint work can be continued, even through distrust is still present.
Hope, faith, confidence, and assurance.

Figure 2. Critical steps during a process of trust repair 


\section{How to Deal With and Repair Broken Trust in an R\&D Partnership}

\section{Anna Brattström}

between individuals. Whereas interpersonal trust repair only requires that one person change their view of another, inter-organizational trust repair requires that multiple individuals change their views - and also that this change of attitude is reflected in the organization's routines.

As illustrated in Figure 2, the first step of trust repair therefore comprises actions to stop the escalation of distrust. This enables partners to continue the collaboration, even though distrust is still present. The second step comprises actions to establish a platform for repairing trust. The main outcome of this step is an expectation that trust violations that happened in the past are less likely to recur. Thereby, the second step creates sufficient conditions for trust to grow, without being subsumed by the distrust present in the $R \& D$ partnership. The third step comprises actions to fully repair trust.
Next, I discuss three specific approaches for stopping escalation, building a platform, and repairing trust - as summarized in Table 1. The first approach is based on apologies, the second is based on control, and the third is based on shielding off. The insights presented are derived from evidence generated through more than a decade of academic research on trust repair (for excellent reviews of the emergent literature on trust repair, see Bachmann et al., 2015; Dirks et al., 2009; Lewicki \& Brinsfield, 2017).

\section{Repair Trust by Making Apologies}

\section{Step 1: Make a clear and credible apology}

An apology is formally defined as a statement that acknowledges responsibility and regret for a trust violation (Kim et al., 2009). Making an apology signals that whatever deceitful behaviour took place was an exception to standard behaviour. Apologies - if accepted - are

Table 1. An overview of the three approaches to repairing trust in an R\&D partnership

\begin{tabular}{|c|c|c|c|c|c|}
\hline \multirow[b]{2}{*}{ Factor } & \multirow[b]{2}{*}{ How It Works } & \multicolumn{3}{|c|}{ Key Activities } & \multirow[b]{2}{*}{ Why It Can Backfire } \\
\hline & & $\begin{array}{l}\text { Step 1. Stop the } \\
\text { escalation of } \\
\text { distrust }\end{array}$ & $\begin{array}{l}\text { Step } 2 . \\
\text { Establish a } \\
\text { platform }\end{array}$ & $\begin{array}{l}\text { Step 3. Repair } \\
\text { trust step-by- } \\
\text { step }\end{array}$ & \\
\hline Apology & $\begin{array}{l}\text { The guilty par(ties) } \\
\text { express regret and } \\
\text { earn forgiveness by } \\
\text { making apologies } \\
\text { and amends. }\end{array}$ & $\begin{array}{l}\text { Make a clear } \\
\text { and credible } \\
\text { apology. }\end{array}$ & $\begin{array}{l}\text { Commit to a full } \\
\text { investigation } \\
\text { and increase } \\
\text { self-monitoring } \\
\text { and control. }\end{array}$ & $\begin{array}{l}\text { Be clear about } \\
\text { expectations } \\
\text { and deal with } \\
\text { sources of } \\
\text { conflict before } \\
\text { they escalate. }\end{array}$ & $\begin{array}{l}\text { - Can be followed by } \\
\text { claims for compensation } \\
\text { - Investigation can } \\
\text { uncover unpleasant facts } \\
\text { - It can be more difficult } \\
\text { when both partners have } \\
\text { violated trust }\end{array}$ \\
\hline Control & $\begin{array}{l}\text { Stability and } \\
\text { predictability are } \\
\text { increased by the } \\
\text { implementation of a } \\
\text { more detailed control } \\
\text { and coordination } \\
\text { structure. }\end{array}$ & $\begin{array}{l}\text { Increase } \\
\text { monitoring and } \\
\text { control in the } \\
\text { R\&D } \\
\text { partnership. }\end{array}$ & $\begin{array}{l}\text { Improve } \\
\text { coordination of } \\
\text { joint activities. }\end{array}$ & $\begin{array}{l}\text { Gradually } \\
\text { decrease } \\
\text { monitoring to } \\
\text { demonstrate } \\
\text { trust and } \\
\text { trustworthiness. }\end{array}$ & $\begin{array}{l}\text { - Monitoring and control } \\
\text { can be interpreted as a } \\
\text { sign of distrust, thereby } \\
\text { fuelling escalation of } \\
\text { distrust }\end{array}$ \\
\hline Shielding Off & $\begin{array}{l}\text { The relationship is } \\
\text { cooled down as less } \\
\text { combative groups are } \\
\text { separated from the } \\
\text { core of the conflict } \\
\text { and trust is repaired } \\
\text { locally among these } \\
\text { groups. }\end{array}$ & $\begin{array}{l}\text { Shield off less } \\
\text { combative } \\
\text { groups from the } \\
\text { core of the } \\
\text { conflict. }\end{array}$ & $\begin{array}{l}\text { Repair trust } \\
\text { locally by } \\
\text { focusing on } \\
\text { solving } \\
\text { problems "here } \\
\text { and now". }\end{array}$ & $\begin{array}{l}\text { Increase } \\
\text { interaction } \\
\text { between groups } \\
\text { in order to allow } \\
\text { locally repaired } \\
\text { trust to diffuse. }\end{array}$ & $\begin{array}{l}\text { - Shielding off less } \\
\text { combative groups } \\
\text { hampers coordination } \\
\text { - Increasing interaction } \\
\text { between groups can also } \\
\text { trigger diffusion of } \\
\text { distrust }\end{array}$ \\
\hline
\end{tabular}




\section{How to Deal With and Repair Broken Trust in an R\&D Partnership}

\section{Anna Brattström}

effective means by which the escalation of a negative spiral can be slowed down. Basically, there are two ways to apologize (Kim et al., 2009). One is to say, "I did it, I accept full responsibility, and I am sorry." The other is to say, "I did it and I am sorry - but I really couldn't help it, since my hands were tied," [or] “...I didn't know it was wrong." Researchers (Harmon et al., 2015; Kim et al., 2006) have shown that, when the transgression relates to lack of honesty, then an apology is more effective if external circumstances can be blamed. This is because accepting full responsibility confirms that the violator was indeed untrustworthy, which can escalate distrust rather than repair trust. If, on the other hand, the transgression relates to lack of competence, then the apology is more credible if the transgressor assumes full responsibility for their wrongdoings.

\section{Step 2: Commit to a full investigation}

Apologies can stop the escalation of distrust but they are not a sufficient platform for subsequently building trust, because "talk is cheap" (Bottom et al., 2002). To be credible, apologies must be followed by action. One such action is to commit to a full investigation of what was done wrong and why (Gillespie \& Dietz, 2009). Rather than identifying scapegoats, this investigation must take a system-wide perspective, reprimanding individuals where necessary and attending to the culture, management practice, and structures that enabled the trust violation to take place.

To further substantiate the apology and build a platform for trust, the investigation should lead to heightened self-monitoring and control. For example, the wrongdoer can open its books to the R\&D partnership partner, allowing full disclosure. This is a way both to signal commitment to the $R \& D$ partnership and to prevent future transgressions. To add further weight to their apology, the transgressor can also institute a selfpunishment (Nakayachi \& Watabe, 2005). This could take the form of an upfront monetary compensation to the other party or a new routine that ensures that the adverse consequences of any further wrongdoings will fall on the wrongdoer themselves. Through such actions, the firm responsible for the trust violation shows that it is serious about reforming its behaviour.

\section{Step 3: Be clear about expectations}

Once a negative spiral has been halted and a platform for trust-building established, it is time to engage in an incremental step-by-step process of trust-building. These activities include being very clear about one's own expectations, aiming to understand the partner's expectations and learning from experience by recognizing potential sources of conflict and dealing with them before they escalate into negative spirals.

\section{How apologies can backfire}

Apologies can be used as long as one partner is willing to accept responsibility for a trust violation. In many $R \& D$ partnerships, however, there are two trust violators, not one, and it can be difficult to sort out who should accept responsibility, and for what. Apologies may also be followed by claims for compensation. If so, denial might be the better strategy. Moreover, any firm that assents to a full investigation of its conduct must be confident that the partner will not find anything that confirms distrust and triggers renewed escalation of conflict. Finally, any firm that invites its partner to monitor its activities must also be confident that the partner will not abuse the information they gain in the process. Since distrust typically goes both ways, such confidence is often lacking. If done wrong, apologies can lead to claims for compensation and even trigger new perceptions of trust violations. The difficult choice that executives need to make is whether they are willing to take all the consequences of accepting responsibility for a trust violation.

\section{Repair Trust by Increasing Control}

\section{Step 1: Increase monitoring and control Consider the following example:}

On January 1, 1992, the Open Skies Treaty came into force, a treaty currently signed by 34 state parties. This treaty enables all participating nations to fly over areas of concern to them and collect information about military forces and activities. Since the treaty was signed, the participating nations have conducted more than 800 such flights over each other's territory, contributing to peace by creating transparency between nations.

The Open Skies Treaty is a good example of how fragile relationships can be stabilized by implementing a control structure that improves monitoring. The equivalent to an Open Skies treaty in the context of R\&D partnerships could be to grant access for mutual crosschecking of information. It could also imply mutual monitoring to make sure that behaviour and outputs were as expected. This type of control structure creates stability by safeguarding against potential opportunism. Thereby, it can stop the escalation of distrust after a trust violation and help to preserve an R\&D partnership. 


\section{How to Deal With and Repair Broken Trust in an R\&D Partnership}

\section{Anna Brattström}

\section{Step 2: Improve coordination}

Even though control and monitoring provide a safeguard, they are not the same thing as trust. In order to build a platform for trust repair, it is important to combine monitoring (which creates assurance against trust violations) with coordination (which helps to align tasks and joint activities) (Brattström \& Bachmann, 2018; Brattström \& Richtnér, 2014). Consider the following example (described by Faems et al., 2008):

At the end of the 1990s, Graph and Jet (pseudonyms), two companies in the image printing industry, initiated an explorative $R \& D$ collaboration. Unfortunately, the R\&D partnership soon ran into unanticipated problems that the partners found it difficult to sort out constructively and collaboratively. After about two years of conflict, the situation became unsustainable and the collaboration was terminated. Whereas this could have been the end of the relationship, the partners instead chose to initiate a second collaboration, despite prevailing mistrust among managers. Jet was low on cash and needed financial support from Graph, while Graph needed access to Jet's advanced technologies (i.e., there were strong interdependencies). Graph and Jet jointly realized the need for a better control structure. They specified in a contract that both companies would conduct similar technological tests and hold joint meetings in which they would share information; they also made it clear what technological activities each expected from the other. In short, they drastically increased the transparency of joint operations in order to facilitate a constructive approach to problem-solving. This new control structure improved the relational climate and eventually contributed to the repair of trust.

Graph and Jet managed to repair trust without either party making an apology. Instead, they implemented a contract that clearly stipulated information exchange and joint problem-solving. Such improvement of coordination is important because there is often a strong, positive link between the successful alignment of activities and trust (Brattström \& Bachmann, 2018). A breakdown in task alignment can raise suspicions that the failure was intentional and deceitful. On the other hand, when the alignment of tasks succeeds and the partner delivers as expected, it is easier to think that the partner is trustworthy. Control structures that facilitate communication, contribute to a shared culture and a shared "language", and they create a joint understanding of the task at hand, which makes it easier to overcome the challenges that emerge during collaborative projects. In this way, coordinative control creates a platform for building trust.

\section{Step 3: Gradually relax monitoring}

The last step is a gradual reduction of monitoring. This enables partners both to demonstrate their own trustworthiness and to signal their trust in each other. In addition, it is important to consider more general trust-building activities, such as clarifying expectations and dealing with conflict before it escalates.

\section{How control can backfire}

Control is an important aspect of all $R \& D$ partnerships, but it can be counterproductive. Instead of inducing stability and predictability in the R\&D partnership, control can be interpreted as a signal of distrust, fueling a negative spiral instead of calming it.

For control to work, partners need a shared understanding of what control is needed and why. In the Open Skies Treaty, all the signatory nations have a common interest in peace and stability, and all agree that aerial surveillance increases the chances of achieving this outcome. In an R\&D partnership between two firms, partners may disagree about who is guilty and in need of control, or what type of control is necessary. If the breach of trust is the result of a series of mutual and escalating transgressions, increased control is particularly likely to be interpreted as an escalation of conflict. To address this, executives must be certain that they and their partner have a clear shared understanding of what control is needed, as well as aligned expectations on where increased control will lead.

\section{Repair Trust by Shielding Off}

Apologies and controls are examples of how a trust violation can be dealt with by directly attacking the rootcause of the problems. By making an apology, the guilty party demonstrates that it is aware of the problem and intends to solve it. By implementing a control structure, the wronged party seeks a constructive way to prevent future transgressions. In comparison, the third approach - shielding off - implies an implicit workaround of the problem at hand. Rather than addressing the cause of the breakdown in trust, this approach is predicated on shielding-off less combative groups from the source of conflict, allowing them to repair trust locally by ignoring the cause of the breakdown. 


\section{How to Deal With and Repair Broken Trust in an R\&D Partnership}

\section{Anna Brattström}

Step 1: Shield off less combative groups from the source of conflict

Consider the following example (described by Brattström et al., 2018):

In 2006, Machine, a global manufacturer of construction equipment, and Cooler Systems, one of its key suppliers, were running a joint development project that was facing serious delays and unforeseen costs. As a result, the collaboration between the two firms became antagonistic at the top management level. Operational engineers, however, had a more constructive dialogue, since they could interact via fact-based reasoning around the technical details of the component being developed. In order to sustain progress in operational tasks, it was therefore decided that communication between engineers and managers would be very restricted, and that engineers would focus on solving practical problems "here and now", disregarding the conflicted past as well as any complicated and uncertain discussions about the future. As it happened, these actions provided the peace and quiet required to soothe the relationship between operational engineers. Later on, a new control structure was implemented in this R\&D partnership, which enabled managers to continue with their hands-off approach and engineers to maintain their focus on daily problem-solving. Eventually, trust became established at the operational level and this trust contributed to a corresponding relational turnaround between managers.

Isolating less combative groups from interaction with more combative groups stops the escalation of conflict within the firm. Escalation across groups is otherwise a common pattern in conflicts (Collins, 2008). Groups that are in conflict often seek "allies", meaning other groups with which they can share gossip and stories, thereby increasing polarization between the conflicting parties. In contrast, shielding off less combative groups helps to damp down the flames of escalation.

Step 2: Let the shielded group focus on practical problemsolving

Once escalation of distrust has been slowed down, the focus shifts to establishing a platform for trust repair. This is done by stimulating local repair of trust among less combative groups, even though other groups within the $R \& D$ partnership may still exhibit distrust. In the $\mathrm{R} \& \mathrm{D}$ partnership between Machine and Cooler, local trust repair was enabled by allowing engineers to focus on solving practical tasks here and now. As engineers began to reason, "we are all engineers", this created a sense of mutual understanding and limited polarization. Over time, sentiments of trust and friendship emerged among engineers, even though distrust remained among corporate managers.

\section{Step 3: Gradually diffuse local trust}

Local trust repair can subsequently function as a platform for repair of trust in more combative groups. An important activity in the final step, therefore, is to increase interaction between groups once more. This allows for a positive trust spiral to take effect as local trust diffuses to other groups. In the $R \& D$ partnership between Machine and Cooler, this took place when one engineer was promoted to the management level. Since he had a more positive attitude towards Cooler, he was able to positively influence trust perceptions among the corporate group.

\section{How shielding-off can backfire}

Like apologies and control, local trust repair also brings disadvantages. First, the approach is only applicable if one group is less combative than the other(s). In many $\mathrm{R} \& \mathrm{D}$ partnerships, distrust permeates all groups that interact with the partner, from corporate managers to operational staff. Another disadvantage is that shielding off can hamper coordination. In the R\&D partnership between Machinery and Cooler, contact between corporate managers and operational engineers was suspended. In this case, this turned out to have a positive effect on trust. However, limiting interaction between managers and operational staff also decreases managers' influence over the firm that they are supposed to be managing and increases the risk that operational staff will engage in behaviour that is not in line with corporate policy.

Finally, the point at which interaction is increased between less and more combative groups is a pivotal moment. While the preferred outcome of this final stage is a diffusion of trust, the actual result could be the spread of distrust, pitching the $R \& D$ partnership partners back into a negative spiral. Before engaging in local trust repair, executives need to make a difficult call: whether they can risk losing control over their internal operations by allowing less combative groups to form local trust with an antagonistic partner, and how they can create the conditions necessary for trust to grow during the final stage. 


\section{How to Deal With and Repair Broken Trust in an R\&D Partnership}

\section{Anna Brattström}

\section{Discussion}

The analysis presented in this article offers core implications both for managers of R\&D alliances and scholars interested in processes of inter-organizational trust repair.

\section{Implications for managers}

1. Exit, acquisition or trust repair are different ways to deal with trust violations. The most important task for executives faced with trust violations is to make sure that the actions they are contemplating will have the results they hope for. Exit should be decisive and constructive - not dragged out over time, leading to excessive losses. Acquisitions should realize synergies - not sweep problems under the carpet or create new ones. When repairing trust, apologies, control, and local trust repair must ensure that trust is strengthened, not weakened even further. Which of these approaches is the most viable requires a careful assessment of the situation in the specific R\&D partnership.

2. You can assess the chances of successfully repairing trust. Not all relationships and trust violations are suitable for apologies, control, or shielding-off. Figure 3 provides checklists that can be used as a basis for reflecting on the chances of successfully repairing trust. The questions raised in the checklist are important because the answers will determine the appropriate way to deal with a specific trust violation. At the same time, these questions are tricky, because they do not have black-or-white answers.

3. Effective trust repair can require a bundle of different approaches. Seasoned executives know that every strategy has the risk of backfiring. What may be most appropriate when seeking to repair trust is to bundle together two or more of these different strategies together. R\&D partnerships are complex and multi-faceted affairs, but they are here to stay. Although it is crucial for their functioning, trust is not a tangible object that can be managed in a transparent and predictable way.

\section{Implications for research}

Dealing with trust violations is an important but challenging task. The emerging literature on trust repair between individuals and organizations offers important insights into this process. Prior work has highlighted two different "tactics" for repairing trust: one based on apologies, the other based on control (Dirks et al., 2009). Whereas the control perspective has been discussed extensively in the context of inter-organizational relationships, the apology perspective has mainly been analyzed in the context of interpersonal relationships. I add to this literature in three specific ways. First, by relating the apology perspective on trust repair to the particular conditions that face managers of interorganizational relationships. Second, by developing local trust as an alternative strategy for repairing trust, which is different from both the apology and control perspective. I do so by synthesizing prior work (Brattström et al., 2018) and relating it to the specific phenomena of trust repair. Finally, my analysis answers calls that have been made for integrative perspectives on trust repair (Bachmann et al., 2015; Dirks et al., 2009; Lewicki \& Brinsfield, 2017). By relating different tactics, such as apologies, control, and shielding-off to a threestep framework (see Figure 3), my analysis allows for a comparison of these different trust repair tactics.

\section{Conclusion}

Even though trust is desirable in R\&D partnerships, it is frequently violated. Dealing with trust violations is therefore a critical part of an executive's job. In this article, I provide an overview of three different options after trust has been violated - exit, acquisition, and trust repair - and outline the pros and cons of each. Addressing the need for managerial advice on how to repair trust, this article provides an actionable framework of trust repair encompassing three critical steps: stopping escalation, building a platform, and repairing trust step by step. 


\section{How to Deal With and Repair Broken Trust in an R\&D Partnership}

\section{Anna Brattström}

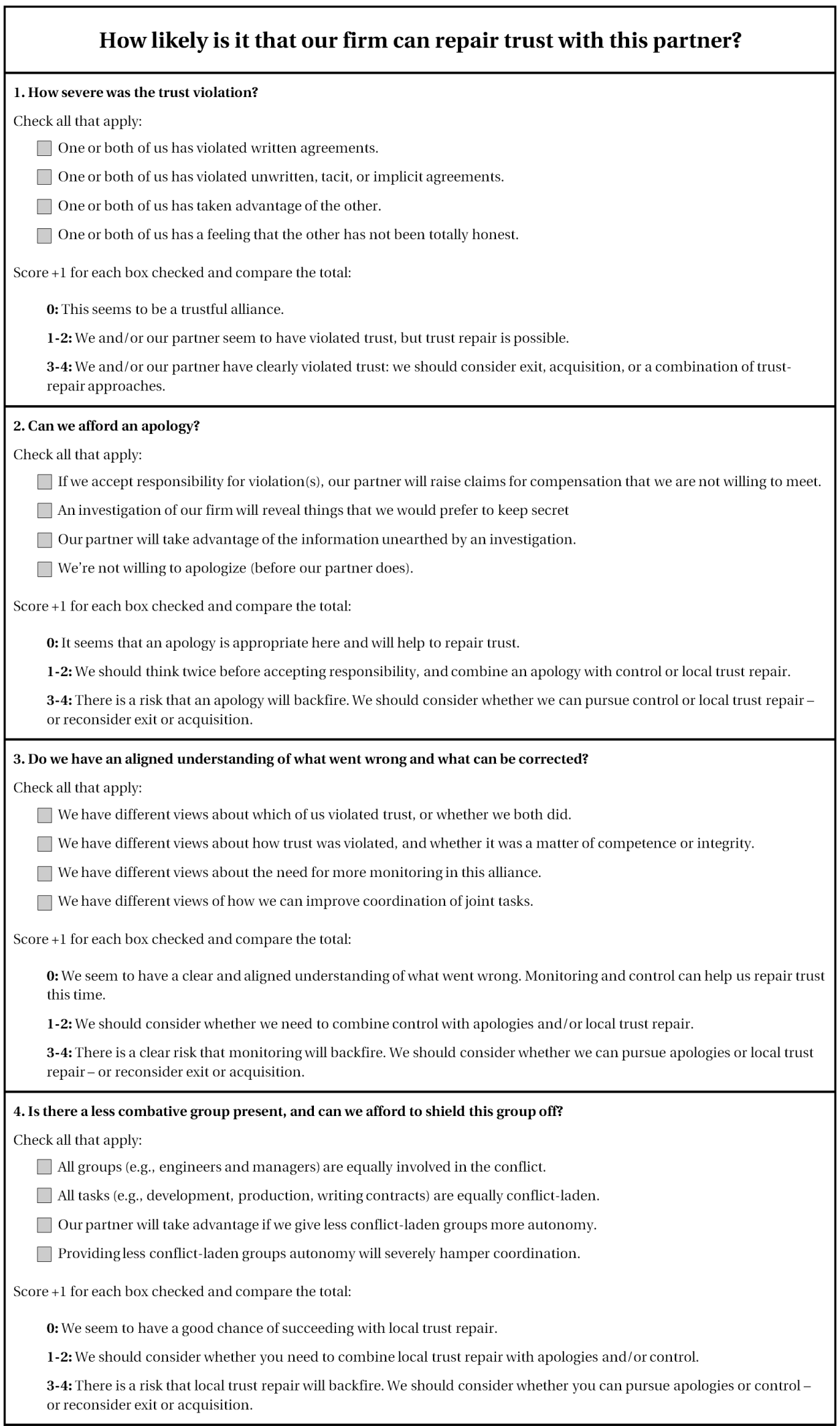

Figure 3. Checklist for assessing the chances of successfully repairing trust in an R\&D partnership 


\section{How to Deal With and Repair Broken Trust in an R\&D Partnership}

\section{Anna Brattström}

\section{About the Author}

Anna Brattström is an Assistant Professor in the School of Economics and Management at Lund University, Sweden, where she researches innovation and collaboration. Her work on trust in $R \& D$ partnerships has been published in journals such as Organization Studies and the Journal of Product Innovation Management. In 2015, she was shortlisted for the ISPIM Innovation Management Dissertation Award for her in-depth studies of trust dynamics in $R \& D$ partnerships.

\section{References}

Ariño, A., \& de la Torre, J. 1998. Learning from Failure: Towards an Evolutionary Model of Collaborative Ventures. Organization Science, 9(3): 306-325.

https://www.jstor.org/stable/2640225

Arino, A., de la Torre, J., \& Ring, P. S. 2001. Relational Quality: Managing Trust in Corporate Alliances. California Management Review, 44(1): 109-131. https://doi.org/10.2307/41166113

Bachmann, R., Gillespie, N., \& Priem, R. 2015. Repairing Trust in Organizations and Institutions: Toward a Conceptual Framework. Organization Studies, 36(9): 1123-1142. https://doi.org/10.1177/0170840615599334

Bottom, W. P., Gibson, K., Daniels, S. E., \& Murnighan, J. K. 2002. When Talk Is Not Cheap: Substantive Penance and Expressions of Intent in Rebuilding Cooperation. Organization Science, 13(5): 497-513.

https://doi.org/10.1287/orsc.13.5.497.7816

Brattström, A., \& Bachmann, R. 2018. Cooperation and Coordination: The Role of Trust in Inter-Organizational Relationships. In A.-M. I. N. Rosalind H. Searle, Sim B. Sitkin (Ed.), The Routledge Companion to Trust: 129-142. London: Routledge.

Brattström, A., Faems, D., \& Mähring, M. 2018. From Trust Convergence to Trust Divergence: Trust Development in Conflictual Inter-Organizational Relationships. Organization Studies, First published August 10, 2018.

https://doi.org/10.1177/0170840618789195

Brattström, A., \& Richtnér, A. 2014. Good Cop-Bad Cop: Trust, Control and the Lure of Integration. Journal of Product Innovation Management, 31(3): 584-598.

https://doi.org/10.1111/jpim.12115

Cartwright, S., \& Cooper, C. L. 1993. The Role of Culture Compatibility in Successful Organizational Marriage. The Academy of Management Executive, 7(2): 57-70.

https://doi.org/10.5465/ame.1993.9411302324

Collins, R. 2008. Violence: A Micro-Sociological Theory. Princeton: Princeton University Press.
Dirks, K. T., Lewicki, R. J., \& Zaheer, A. 2009. Repairing Relationships Within and Between Organizations: Building a Conceptual Foundation. Academy of Management Review, 34(1): 68-84. https://doi.org/10.5465/amr.2009.35713285

Doz, Y. L. 1996. The Evolution of Cooperation in Strategic Alliances: Initial Conditions or Learning Processes? Strategic Management Journal, 17: 55-84.

https://doi.org/10.1002/smj.4250171006

Faems, D., Janssens, M., Madhok, A., \& Van Looy, B. 2008. Toward an Integrative Perspective on Alliance Governance: Connecting Contract Design, Trust Dynamics, and Contract Application. Academy of Management Journal, 51(6): 1053-1078. https://doi.org/10.5465/amj.2008.35732527

Gillespie, N., \& Dietz, G. 2009. Trust Repair after an OrganizationLevel Failure. Academy of Management Review, 34(1): 127-145. https://www.jstor.org/stable/27759989

Gulati, R., \& Nickerson, J. A. 2008. Interorganizational Trust, Governance Choice, and Exchange Performance. Organization Science, 19(5): 688-708.

https://doi.org/10.1287/orsc.1070.0345

Gulati, R., Sytch, M., \& Mehrotra, P. 2008. Breaking Up Is Never Easy: Planning for Exit in a Strategic Alliance. California Management Review, 50(4): 147-163. https://doi.org/10.2307/41166460

Hagedoorn, J. 2002. Inter-Firm R\&D Partnerships: An Overview of Major Trends and Patterns since 1960. Research Policy, 31(4): 477-492. https://doi.org/10.1016/S0048-7333(01)00120-2

Harmon, D. J., Kim, P. H., \& Mayer, K. J. 2015. Breaking the Letter Vs. Spirit of the Law: How the Interpretation of Contract Violations Affects Trust and the Management of Relationships. Strategic Management Journal, 36(4): 497-517.

https://doi.org/10.1002/smj.2231

Kim, P. H., Dirks, K. T., \& Cooper, C. D. 2009. The Repair of Trust: A Dynamic Bilateral Perspective and Multilevel Conceptualization. Academy of Management Review, 34(3): 401-422.

https://doi.org/10.5465/amr.2009.40631887

Kim, P. H., Dirks, K. T., Cooper, C. D., \& Ferrin, D. L. 2006. When More Blame Is Better Than Less: The Implications of Internal Vs. External Attributions for the Repair of Trust after a CompetenceVs. Integrity-Based Trust Violation. Organizational Behavior and Human Decision Processes, 99(1): 49-65. http://psycnet.apa.org/doi/10.1016/j.obhdp.2005.07.002

Krishnan, R., Martin, X., \& Noorderhaven, N. G. 2006. When Does Trust Matter to Alliance Performance? Academy of Management Journal, 49(5): 894-917. https://doi.org/10.5465/amj.2006.22798171

Kroeger, F. 2012. Trusting Organizations: The Institutionalization of Trust in Interorganizational Relationships. Organization, 19(6): 743-763.

https://doi.org/10.1177/1350508411420900

Kunttu, I. 2017. A Managerial Decision Tool for R\&D Outsourcing and Partner Selection in High-Technology Industries. Technology Innovation Management Review, 7(3): 25-32. http://doi.org/10.22215/timreview/1062

Lewicki, R. J., \& Brinsfield, C. T. 2017. Trust Repair. Annual Review of Organizational Psychology and Organizational Behavior, 4(13): $1-27$. https://doi.org/10.1146/annurev-orgpsych-032516-113147 


\section{How to Deal With and Repair Broken Trust in an R\&D Partnership}

\section{Anna Brattström}

Lewicki, R. J., McAllister, D. J., \& Bies, R. J. 1998. Trust and Distrust: New Relationships and Realities. The Academy of Management Review, 23(3): 438-458.

https://doi.org/10.5465/amr.1998.926620

Lewicki, R. J., \& Wiethoff, C. 2000. Trust, Trust Development, and Trust Repair. In M. Deutsch, \& P. T. Coleman (Eds.), The Handbook of Conflict Resolution: Theory and Practice: 86-107. San Francisco, CA: Jossey-Bass.

Mayer, R. C., Davis, J. H., \& Schoorman, F. D. 1995. An Integration Model of Organizational Trust. The Academy of Management Review, 20(3): 709-734.

https://doi.org/10.5465/amr.1995.9508080335

Moraes, E. 2010. Assessing Trust between Members of a Marketplace. Open Source Business Resource, September 2010: 26-28.

http://timreview.ca/article/380

Nakayachi, K., \& Watabe, M. 2005. Restoring Trustworthiness after Adverse Events: The Signaling Effects of Voluntary "Hostage Posting” on Trust. Organizational Behavior and Human Decision Processes, 97(1): 1-17.

http://psycnet.apa.org/doi/10.1016/j.obhdp.2005.02.001

Pfeffer, J., \& Salancik, G. R. 1978. The External Control of Organizations: A Resource Dependence Perspective. New York: Harper and Row.

Poppo, L., Zhou, K. Z., \& Li, J. J. 2016. When Can You Trust "Trust”? Calculative Trust, Relational Trust, and Supplier Performance. Strategic Management Journal, 37(4): 724-741.

https://doi.org/10.1002/smj.2374

Zaheer, A., McEvily, B., \& Perrone, V. 1998. Does Trust Matter? Exploring the Effects of Interorganizational and Interpersonal Trust on Performance. Organization Science, 9(2): 141-159.

https://doi.org/10.1287/orsc.9.2.141

Citation: Brattström, A. 2018. How to Deal With and

Repair Broken Trust in an R\&D Partnership. Technology

Innovation Management Review, 8(9): 4-15.

http://doi.org/10.22215/timreview/1182

Keywords: open innovation, R\&D partnerships, trust, conflict, trust repair 


\section{Academic Affiliations and Funding Acknowledgements}

Canadà
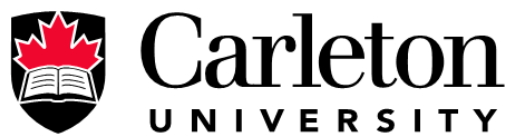

U N I V E R S I T Y

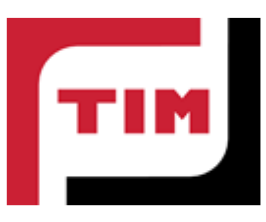

The Federal Economic Development Agency for Southern Ontario (FedDev Ontario; feddevontario.gc.ca) is part of the Innovation, Science and Economic Development portfolio and one of six regional development agencies, each of which helps to address key economic challenges by providing regionallytailored programs, services, knowledge and expertise.

- The TIM Review receives partial funding from FedDev Ontario's Investing in Regional Diversification initiative.

Technology Innovation Management (TIM; timprogram.ca) is an international master's level program at Carleton University in Ottawa, Canada. It leads to a Master of Applied Science (M.A.Sc.) degree, a Master of Engineering (M.Eng.) degree, or a Master of Entrepreneurship (M.Ent.) degree. The objective of this program is to train aspiring entrepreneurs on creating wealth at the early stages of company or opportunity lifecycles.

- The TIM Review is published in association with and receives partial funding from the TIM program. 